Article in press

\title{
Fostering Digital Entrepreneurship from startup to scaleup: The role of Venture Capital funds and Angel Groups
}

Please cite as: Cavallo et al., 2019.

Full Reference: Cavallo, A., Ghezzi, A., Dell'era, C. and Pellizzoni, E., (2019). Fostering Digital Entrepreneurship from startup to scaleup: The role of Venture Capital funds and Angel

Groups. Technological Forecasting and Social Change, 145, 24-35.

https://doi.org/10.1016/i.techfore.2019.04.022

\section{Angelo Cavallo*, Antonio Ghezzi, Claudio Dell'era, Elena Pellizzoni}

\author{
Angelo Cavallo* \\ Politecnico di Milano, Department of Management, Economics and Industrial Engineering, Via \\ Lambruschini, 4/B, 20156 Milano, Italy. \\ E-mail: angelo.cavallo@polimi.it. \\ Antonio Ghezzi \\ Politecnico di Milano, Department of Management, Economics and Industrial Engineering, Via \\ Lambruschini, 4/B, 20156 Milano, Italy. \\ E-mail: antonio1.ghezzi@polimi.it \\ Claudio Dell'Era \\ Politecnico di Milano, Department of Management, Economics and Industrial Engineering, Via \\ Lambruschini, 4/B, 20156 Milano, Italy. \\ E-mail: claudio.dellera@polimi.it \\ Elena Pellizzoni \\ Politecnico di Milano, Department of Management, Economics and Industrial Engineering, Via \\ Lambruschini, 4/B, 20156 Milano, Italy. \\ E-mail: elena.pellizzoni@polimi.it
}

\footnotetext{
* Corresponding author
} 


\title{
Fostering Digital Entrepreneurship from startup to scaleup: The role of Venture Capital funds and Angel Groups
}

\begin{abstract}
Digital entrepreneurship highly relies on external sources of financing to foster growth. This study aims at investigating how angel groups and venture capital (VC) funds affect growth of digital new ventures in their startup and scaleup phase. To address this aim, we analyzed 372 investment rounds regarding 256 Italian-based new ventures. The key findings are fourfold. First, VC funds positively affect the growth of digital new ventures. Second, digital scaleups, in line with the overall sample of digital new ventures, show a linear path of growth positively correlated with VC funding. Third, the relationship between funding received and growth in digital startups follows an inverted U-shapewith the optimal level within our sample set at 300,000\$. Finally, no evidence emerges on the angel groups contribution to the growth of digital new ventures in both startup and scaleup phase. These findings are hence discussed in the light of extant literature on venture financing as well as entrepreneurial bias literature, to provide insight for both researchers and practitioners in digital entrepreneurship.
\end{abstract}

\section{Keywords}

Digital Entrepreneurship, Startup, Scaleup, New Ventures, Angels, Venture Capitalist 


\section{INTRODUCTION}

This study examines the role of venture capital (VC) funds and angel groups in explaining digital new ventures growth, with particular reference to two different stages: startup and scaleup. Recently, an increasing attention from both scholars and leading political institution is focusing on digital new ventures growth (European Commission, 2015). Digital new ventures relevance for research is evolving from just being a suitable empirical setting to a distinct and emergent filed in need of theorizing (Nambisan, 2017; Steininger, 2019). Literature using digital as empirical setting (and, as sub-component of the wider hi-tech sector) with the intent to capture innovative initiatives considered to have a major impact on economic growth (Colombo and Grilli, 2005) - is being flanked by studies that are willing to move forward and push research into an original research field: Digital Entrepreneurship.

Digital Entrepreneurship includes those studies exploring and (possibly) theorizing on entrepreneurial processes, outcomes and agency transformed by digitization, or by rephrasing it as digital transformation of entrepreneurial processes, outcomes and agency (Nambisan, 2017). Digital technologies such as artificial intelligence, crowdfunding platforms, digital 3D printing, social media platforms, big data, cloud and mobile are originating a wide spectrum of opportunities leading to new ways of pursuing entrepreneurship (von Briel, et al., 2018). Digital technologies enabled the creation of new entrepreneurial outcomes such as digital artifact (e.g. mobile apps) or digital platform as store of digital artifact (e.g. Apple store and Google store), and they are inherently different from other entrepreneurial outcomes in terms of speed of production and diffusion (Parker et al., 2016). Digitization of the entrepreneurial outcomes allows to introduce to the market "beta-version" to test and improve the value offered, thus emphasizing the experimental nature of entrepreneurial process, which for instance explains the success of the lean startup approaches (Ries, 2011; Ghezzi and Cavallo, 2018).

The entrepreneurial process is changing also with reference to the number agents involved, which can interact and exchange knowledge through enabling digital technologies. Entrepreneurial agency, which had historically been considered a matter of individual-opportunity nexus (Shane and Eckhardt, 2003), is now embracing a broader perspective, to reach a systemic or eco-systemic view (Malecki, 2018; Cavallo et al., 2018b).

In this regard, scholars in venture financing can be considered as precursors of such broader perspective, as they emphasized the relevance of external players as venture capital (VC) funds or angels which provided new ventures with funding. Within the field of entrepreneurship, a prominent 
attention has been dedicated to venture financing as a factor explaining growth (Hellmann and Puri, 2000; Davila et al., 2003). Relevant contributions argue how external funding may add value to portfolio companies by providing certification effect when coming from venture capitalist (e.g. Dimov and Shepherd, 2005; Puri and Zarutskie, 2012) as well as angels (e.g. Carpentier and Suret, 2015).

Nowadays, the equity funding landscape displays a great variety of sources (Drover et al., 2017). Newly emerged forms of investors, such as equity crowdfunding platforms and accelerators, enriched the variety of risk capital sources besides traditional forms, like 'formal' venture capital funds and 'informal' angel investors (Bruton et al., 2010). Moreover, new trends and dynamics recently emerged in venture financing among angels and VC funds. With reference to these phenomena, there has been a proliferation angel grouping across the globe (Kerr et al., 2011). By means of resource pooling, angel groups may invest in later stages with a larger amount, partially overlapping to the action space traditionally occupied by VC funds (Hellmann and Thiele, 2015). According to Carpentier and Suret (2015), a professionalization and formalization of the angel market (historically considered as informal VC market) is taking place, which is leading angels to act and impact similarly to VCs. Also, VC funds demonstrate a growing interest in earlier stages than in the past (Dutta and Folta, 2016). Those new trends involving both angels and VC funds may be perceived as an answer to the higher level of uncertainty (as well as new opportunities) brought in by digital technologies, which are leading to an increased unpredictability and non-linearity of new ventures growth (Huang et al., 2017; Nambisan, 2017).

Concerning digital new venture growth, an emergent model is gaining attention among both scholars and practitioners (Blank, 2013; Isenberg and Onyemah, 2016; Huang, et al.; 2017; Autio et al., 2018; Srinivasan and Venkatraman, 2018). The model applies particularly to digital entrepreneurship and is based on a fundamental distinction between startups still working on validating their business model and scaleups showing significant metrics of traction on customers, and being already funded through a first Series 'A' round - over 1 million \$ (Autio, 2016). This distinction in the early phase of growth between startups and scaleups is worth studying, to enhance our understanding on digital entrepreneurship (Srinivasan and Venkatraman, 2018). Hence, recent research developments open to further contributions on digital new ventures growth process and the role of emerging venture financing trends involving angel groups and $\mathrm{VC}$ funds.

We know that VC funds and Angels have been important for the growth of new ventures; what we do not know is if their role is still that relevant in a context characterized by a) more and more agents involved in the entrepreneurial process, b) new trends in venture financing landscape, and c) highly Cavallo et al., (2019). Fostering Digital Entrepreneurship from startup to scaleup: The role of 4 Venture Capital funds and Angel Groups 
influenced by digital technologies. This is a key, though unanswered, question in the current research debate.

Enhancing our understanding over the role of angel groups and VC funds to foster digital new ventures growth in their early phase of startup and scaleup is useful, given that: (i) few studies analyze digital new ventures growth process, which radically differs from traditional organization growth in terms of unpredictability and non-linearity (Huang et al., 2017; Nambisan, 2017), and basically no research specifically refers to startup and scaleup phase - where these features are even more evident; (ii) few studies focused on angel grouping (Lerner et al., 2018; Carpentier and Suret, 2015), and even less focus was placed on comparing angel groups with VC (Dutta and Folta, 2016) - which are increasingly overlapping their action-space in the funding process (Drover et al., 2017) and; iii) today, leading political institution (European Commission, 2015) as well as a plethora of actors belonging to the wide entrepreneurial ecosystem (Cavallo et al., 2018b) are calling for research on how to foster digital entrepreneurship. In view of these arguments, this study addresses the following overarching question: How VC funds and Angel Groups may influence digital new ventures growth in their startup and scaleup phases?

To cope with such research question, we base our investigation on 372 investment rounds representing our sample cases - regarding 256 digital new ventures in startup and scaleup phases that received investments from angel groups and VC funds in the time span 2012-2017. Data analysis has been performed trough a linear regression. Revenue growth represents our dependent variable (Delmar, 2006), while the amount of investments provided by VC funds or angel groups are employed as independent variables. Data on investments rounds were collected through annual surveys on the main Italian-based investors, complemented also by other secondary sources. Hence, this study will focus on the Italian context as its empirical setting. While prior research had been mainly focused on US Venture Capital (VC) market, less attention has been dedicated to underdeveloped VC markets like those in Southern Europe (Bertoni et al., 2011). This adds originality to this research also in terms of empirical setting.

Our findings suggest that VC funds positively affect the growth of digital new ventures, while no evidence emerges on the angel groups' contribution. Moreover, by focusing on digital startup and digital scaleups - as two distinct stages of growth of digital new ventures - and the relative subsamples, two additional insights emerge from this study. First, digital scaleups, in line with the overall sample of digital new ventures, show a linear path of growth positively correlated with VC funding. Second, contrarily to our expectation, digital startups - as the amount of funding increased - at first grew and then shrank after an optimal level of 300,000\$ invested in them. 
The remainder of the paper consists in five sections. After introducing the context and the research objectives, we provide the theoretical background underlining two sets of hypotheses (Section2). This is followed by Section 3 that illustrates the research design and the methodology employed in this study. Section 4 then presents econometric analysis and results. Finally, Section 5 and Section 6 respectively discuss the results and conclude the study by focusing explicitly on research value and relative policy implications.

\section{THEORETICAL BACKGROUND}

\subsection{Digital New Venture Growth}

Organizations grow through multiple stages over their lifetime. This process has been along debated in the literature for about fifty to sixty years (e.g. Penrose, 1959; Galbraith, 1982; Mintzberg, 1984; Phelps et al; 2007; Fisher et al., 2016) providing several models, both linear (e.g. Greiner, 1972) and non-linear (e.g. Orser et al., 2000). The literature mainly deals with rapidly growing hi-tech new ventures (e.g. Phelps et al; 2007). As regards, an early and remarkable contribution in this direction and specifically focused on technology-based ventures comes from Galbraith (1982). This population of ventures captures higher attention due to the extreme pressures they experience while growing and their supreme need for adaptation and change (Phelps et al; 2007). Technology (including digital technology) has been treated in entrepreneurship literature as a context for empirical work (e.g. Colombo and Grilli, 2005; Cavallo et al., 2018a; Hahn at al., 2018). Today, an ongoing debate is recognizing a superior and pervasive role of digital technologies into entrepreneurial process and outcome (Nambisan, 2017), and, thus, in digital new venture growth. Digital Technologies are a powerful tool deeply influencing digital new venture growth by creating affordances to quickly scale (Autio et al., 2018).

An emerging model of organization growth is gaining attention among both scholars and practitioners which applies particularly to the digital entrepreneurship. Indeed, the model captures a fundamental feature brought by digitalization, i.e. scalability, and it is based upon a fundamental distinction: startups vs scaleups (Blank, 2013; Isenberg and Onyemah, 2016; Huang, et al., 2017; Srinivasan and Venkatraman, 2018). Prior research already analyzed the scaling process (Chandler, 1962), although building on classical economies of scale and standardization rather than based on exploiting digital Cavallo et al., (2019). Fostering Digital Entrepreneurship from startup to scaleup: The role of 6 
technologies potential. Stam et al., (2012), also highlight a distinction between the 'average' entrepreneur and ambitious entrepreneur seeking to quickly scaleup. According to recent contributions, digital startups typically are committed to testing and validating their business model, while digital scaleups already show significant traction on customers, a validated business model, and they have been funded through a first Series 'A' round - over 1 million \$ (Autio, 2016).

Proving a constant growing demand or a higher interest in the value proposition from the customers is commonly perceived by venture capitalists as signal of "traction" and (more importantly) as signal of a proven business model. The matter is so crucial that the answer provided by entrepreneurs will determine the very success of a fundraising process. A twofold reason testifies the complexity and fuzziness characterizing the concept of traction. First, metrics of traction may vary significantly (also within the digital sector) according to the specific product-market addressed by the firm (Onetti, 2014). Second, scholars argue that user base (Prasad et al., 2010) rather than customer base is the heart of the rapid scaling (Huang, et al.; 2017). Delmar (2006) pointed out that the growing demand is the first stage of new ventures' growth process, which it will consequently lead to higher sales and to hire new employee. Thus, digital new ventures with high growth in sales or employee may be realistically considered as firms that are successfully embracing and overcoming the scaling phase. Recently, when referring to 'successful' scaleups, scholars also used the term gazelles (Duruflé, et al., 2017) as to indicate firms that are rapidly growing (e.g. Birch et al., 1993; Henrekson and Johansson, 2010). Even though there is no complete agreement among scholars (March and Sutton, 1997), the most widely used threshold which defines "gazelles" (Birch et al., 1993; Henrekson and Johansson, 2010) is having a yearly sales growth rate of at least $20 \%$ for three or more consecutive years (Fischer and Reuber, 2011; Sims and O'Regan, 2006). In this study, we will focus particularly on the earlier and thus most critical growth stages: startup and scaleup. In particular, based on the literature before mentioned, the letter will include only those new digital firms entering the scaling phase (by receiving a first Series 'A' round), not yet considerable as gazelles.

\subsection{Venture financing}

Within the field of entrepreneurship, a prominent attention has been dedicated to venture financing as explaining factor for new venture growth (Hellmann and Puri, 2000; Davila et al., 2003). Risk (or Equity) capital is an essential resource for new venture growth. According to the literature, hi-tech (thus, including digital) new ventures may particularly suffer from a financial gap (Wetzel, 1983; Timmons and Bygrave, 1986). Digital new ventures are expression of hi-growth potential as well as 
high risk profile and commonly require funding far beyond founders' and family savings. Nowadays, the equity funding landscape presents a great variety of sources (Drover et al., 2017). Initially, new ventures will be financed from 'internal' sources i.e. founders' or family and friends' savings or by generating some form of income with early product developments. This is the so called 'Bootstrapping', a common practice especially among software entrepreneur - which acts as an alternative or complementary source of capital in the very early new venture stages (Freear et al, 1994; Freear et al, 2002). Subsequently, private individuals or 'angels' operating outside formal financial institutions are willing to invest their own resources in new business, originating an 'informal' venture capital market (Wetzel, 1983). When the new ventures are able to show some form of track record, they have built a proven business model and are in need of a larger amount of funding, then it is time to approach a formal financial institution such as independent venture capital fund and corporate venture capital fund (Hellmann and Thiele, 2015). Recently, other forms enriched the variety of risk capital sources such as equity crowdfunding platforms, accelerators, microfinance and peer to peer landing (Khavul, 2010; Bruton et al., 2015). Even though mostly focused on the earliest stages of the venture, those sources of risk capital may act as substitute or complement of the traditional ones.

Research on venture financing started to gain momentum in the early 1980 s, following the first "big wave" of tech-entrepreneurship (1950s-1960s). Since then, considerable research has been conducted on formal venture capital funds which mainly entails financial institutions such as venture capital (VC) and corporate venture capital (CVC) fund ${ }^{1}$ (Drover et al., 2017). Most of the literature on formal venture capital has been focused on VC rather than CVC funds (Drover et al., 2017). In particular, research has been focused on VC decision-making process (e.g. Tyebjee and Bruno, 1984; Dimov and Shepherd, 2005; Petty and Gruber, 2011) as well as on the principle-agent framework characterizing the investor-entrepreneur relationship (Sapienza and Gupta, 1994; Hellmann and Puri, 2002). Several researchers provided valuable contributions on VC at organizational level. Central areas of inquiry were: VC strategies to cope with uncertainty and agency cost (e.g. Cumming, 2008; Tian, 2011); and the role of VC funds in adding value to portfolio companies and providing certification effects (e.g. Dimov and Shepherd, 2005; Puri and Zarutskie, 2012). Ultimately, research

\footnotetext{
${ }^{1}$ Venture Capital funds (VC), managed by independent general partners, raise funds from limited partners (typically: pension funds, banks and government funds), providing them a return by investing in hi-growth and innovative companies (Gompers and Lerner, 2000). Corporate Venture Capital funds (CVC) differ from traditional VC, since are typically sponsored by a company (Gompers, and Lerner, 2000). 
on exogenous factors affecting the VC funds action-space (e.g. Grilli and Murtinu, 2014; Guerini and Quas, 2016; Minola, Vismara and Hahn, 2017) is gaining attention among scholar. Although it has been extensively researched, VC is not considered the main risk capital's source. Indeed, angel or 'informal' investors are widely recognized in the literature as the largest source of risk capital (Wetzel, 1983; Mason and Harrison, 1992).

The informal venture capital market involves transaction in private equity securities not subject to the rigorous disclosure requirements for public entities, and there is almost no institutional infrastructure supporting the market (Prowse, 1998). In venture financing literature, much less attention has been dedicated to the informal venture capital compared to the formal one (Gompers and Lerner, 2001; Kerr et al., 2011). Starting from seminal works by Wetzel (1981,1983), scholars investigated issues such as the size of the informal venture capital market (Mason and Harrison, 1992, 2000), investor characteristics (Sørheim and Landström, 2001), decision process, information channels, private and public initiatives to stimulate the informal venture capital market (Fairchild, 2011). The literature has shown some difficulties in identifying investor operating in the informal venture capital market, known as angels or business angels (Wetzel, 1981). Even when we are able to identify the investors, they may be reluctant to participate in a study, since they prefer to remain anonymous (Sørheim and Landström, 2001). Harrison and Mason (1992) tried to address and partially face this issue by providing three methods of identifying angel investors, but this still remains an unsolved problem. Recently, researchers have coped with this challenge by focusing on angel investment organizations or angel groups (Carpentier and Suret, 2015; Sohl, 2012). Moreover, research on angel groups, while emerging only recently, is gaining a lot of attention especially due to the consistent trend of proliferation of angel grouping across the globe (Drover et al., 2017). Angel groups often actively participate to the new venture development, providing essentially advice and contacts. Usually, they follow a structured deal screening process before any investment, due to the greater resources available as a group (Kerr et al., 2011). Moreover, those groups are more visible to entrepreneurs and thus receiving a superior deal flow (Kerr et al., 2011). According to Carpentier and Suret (2015), a professionalization and formalization of the angel market (historically considered as informal VC market) is taking place, which is leading angels to act and impact similarly to VCs. However, few studies investigated angel groups and even fewer compared them with VC (Dutta and Folta, 2016).

In line with the literature surveyed, in this study, we will focus on angel groups and on venture capital (VC) funds. 


\subsection{Linking VC funds and Angel groups with Digital New Venture Growth}

The recent trend of angel groups is triggering the traditional linear investment process where informal typically precede formal investors (Wilson, 2011). By means of resource pooling, angel groups may invest in later stages with a larger amount, thus partially overlapping the action space traditionally occupied by venture capital (VC) funds (Hellmann and Thiele, 2015). Besides, VC funds demonstrate a growing interest in earlier stages than in the past (Dutta and Folta, 2016). This leads researcher to open a new and current debate over the beneficial but possibly substitutable role of $\mathrm{VC}$ and angel groups affecting the growth of digital new ventures.

There is a widespread agreement among scholars over the beneficial impact of $\mathrm{VC}$ on portfolio companies mainly based on signaling theories (e.g. Gompers and Lerner, 2001; Hellmann and Puri, 2002). Scholars explain the positive impact of venture capitalists on new ventures based on their role in reducing problems linked to asymmetric information and moral hazard (Gompers and Lerner, 2001). VCs are investors providing critical components for early stage new ventures' survival, such as contacts, information, and managerial knowledge (Bertoni et al., 2011; Sorenson and Stuart, 2001). New ventures backed by VC may benefit from a higher credibility and visibility, enhancing their chances to search for partners, attract customers and human capital (Stuart et al., 1999). These explanations fall under the "treatment effect", where the positive association between VC involvement and new ventures growth is due to financial and non-financial support VCs offer to the portfolio companies (Bertoni et al., 2011). Other scholars argue that VC-backed new ventures outperform the non-VC backed new ventures, since typically VCs own superior scouting capabilities (e.g. Chan, 1983; Amit et al., 1998). This explanation is known in literature as "selection effect" or "pick winners" (Baum and Silverman, 2004; Bertoni et al., 2011; Zacharakis and Meyer, 2000). Empirical evidences show that "treatment effect" may result as prevailing over the "selection effect" (see Bertoni et al., 2011; Colombo and Grilli, 2005; 2010).

Other theories supporting the positive role of VC on new venture growth stem from governance and finance literature (Dutta and Folta, 2016). VC monitor their portfolio companies through efficient contract covenants and board membership. This enhances the establishment of a structured governance and formal procedures, which is something new ventures in their early stage usually lack and need. Implementing efficient governance mechanisms has proved to positively impact growth and performance of companies (Sapienza, 1992).

Not only the VC governance, but also the investment structure and process may support the positive role of VC on new ventures growth. VCs are known as investment funds with high incentives to exit 
in a time frame (Berglof, 1994) which is typically not over 10 years. As a result, they are prone to achieve exit and positive returns as such the entrepreneurs on which they have committed their funds. This may enhance and facilitate the new venture development process (Dutta and Folta, 2016).

Based on the aforementioned theories, the literature showing that VC positive impacts new ventures growth is abundant (e.g. Chemmanur et al., 2011; Audretsch and Lehmann, 2004; Puri and Zarutskie, 2008). Moreover, studies revealed that the positive effect of $\mathrm{VC}$ to the growth of new ventures is especially evident in early stage and hi-tech new ventures (e.g. Stuart et al., 1999; Bertoni et al., 2011; Colombo and Grilli, 2005). Davila et al. (2003), while grounding their study in the signaling theories, highlight that VC investments may result beneficial founders' growth plan especially in markets with high uncertainty and complexity. Both uncertainty and complexity are there to stay (Dosi et al., 2003), and possibly, grow, in a digital world. Thus, it is likely that previous literature may apply to digital new ventures growth - intending digital as a sub-component of hi-tech sector.

However, recent developments in (digital) entrepreneurship literature may contrast this assumption. The progressive advancement of technologies inherently digital is deeply influencing entrepreneurship, for instance, by modifying entrepreneurial boundaries - in terms of process and outcome - and entrepreneurial agency - which refers to the increasing number of players and actors involved in a collective way of pursuing entrepreneurship (Nambisan, 2017; von Briel et al., 2018; Srinivasan and Venkatraman, 2018). Among these actors and players, VC funds, which provide external funding, may realistically have impact on the growth of digital new ventures - just like the literature traditionally recognized for technology-intensive new ventures. Besides, some may argue that, due to entrepreneurial agency, $\mathrm{VC}$ impact is still relevant but less significant for digital new ventures growth, which may rely on other sources to gather resources to foster their growth, and thus, affecting their centrality in venture financing. We believe that this is not the case, since digital new ventures navigate in an even more uncertain digital world (Nambisan, Siegel and Kenney, 2018) than in the past, and that a signal of quality - as receiving funding from professional VC fund would be is the premise to subsequently attract other agents which may join and support the entrepreneurial process.

In view of the arguments provided, the following first hypothesis can be advanced:

Hypothesis 1.1: The amount of Venture Capital investment provided by VC funds positively impacts Growth of Digital Ventures. 
In addition, we argue that VC may have major impact especially when uncertainty is higher such as in the very early stages of digital new venture development (Stuart et al., 1999; Bertoni et al., 2011; Colombo and Grilli, 2005), that is, startup and scaleup (Autio, 2016). As a result, we expect evidences of the beneficial impact of VC for both startups and scaleups:

\section{Hypothesis 2.1: The amount of Venture Capital investment provided by VC funds positively impacts Growth of Digital Startups.}

\section{Hypothesis 3.1: The amount of Venture Capital investment provided by VC funds positively impacts Growth of Digital Scaleups.}

The venture financing literature also provides valuable studies focused on angel-backed companies (e.g. Kerr et al., 2011; Bruton et al., 2010). Croce et al. (2016) show how angels' experience may have a beneficial impact on new venture growth. Hellmann and Puri (2002) highlight that angels play an active role in professionalizing those firm in which they invest. Angels typically are former entrepreneurs or industry executives whose managerial experience and personal network of contacts may assist and foster venture development and performance, similarly to VC funds (Wong et al., 2009). In sum, the theoretical rationale of investors signaling firm quality, reducing asymmetric information and moral hazard and fostering the growth of portfolio's companies applies to angels as well as VC (Elitzur and Gavious, 2003; Van Osnabrugge and Robinson, 2000). This theoretical rationale not only can be extended, but is especially valid for groups of angels, since angel groups apply a more professional approach to investing than independent angels do (Collewaert, 2012; Sohl, 2012). Being a recent phenomenon, few studies focused specifically on angel groups, while much interest has been dedicated to independent angels. Angel group members are active investors providing network of contacts, access to strategic partners and high potential human capital (Van Osnabrugge and Robinson, 2000; Dutta and Folta, 2016). As regard, Kerr et al., (2011) find evidence of a positive impact generated by two leading angel groups to new venture performance. By mean of resource pooling, angel groups have more financial firepower, thus giving them the ability to provide larger amounts also in later stages as follow-on of an initial investment (May, 2002; Payne and Macarty, 2002). Angels' investment decision usually relays on the funders' trust and passion perceived by angels (Prowse, 1998), rather than a formal due diligence process as for VC funds. However, by grouping angels might sustain more costly and structured due diligence process, thus 
becoming more efficient in the deals screening process (May, 2002). Similarly to VC, angel groups are using complex contracts (Sohl, 2012) and support the portfolio's companies to build a strong and structured governance.

To conclude, angel groups appear very similar to VC over many aspects (such as: investment target and process, financial and non-financial support provided to portfolio companies etc) (Sohl, 2012; Carpentier and Suret, 2015), and based on the same theoretical foundation, we expect that angel groups have a positive impact on digital new venture growth.

Hypothesis 1.2: The amount of Venture Capital investment provided by Angel Groups positively impacts on Growth of Digital Ventures

Moreover, by grouping, angels tend to operate in overlapping with the traditional action space of VC funds (Hellmann and Thiele, 2015; Carpentier and Suret, 2015). Therefore, we expect a positive impact in both startup and scaleup phase:

Hypothesis 2.2: The amount of Venture Capital investment provided by Angel Groups positively impacts on Growth of Digital Startups.

Hypothesis 3.2: The amount of Venture Capital investment provided by Angel Groups positively impacts on Growth of Digital Scaleups.

\section{SAMPLE AND VARIABLES}

\subsection{The sample}

Our database consists of financial data concerning 653 Italian new ventures. In particular, we built a longitudinal dataset by collecting data on 840 investment rounds - as sample cases of this study provided by angel groups (AG) and venture capital funds (VC) investing in hi-tech and hi-growth new ventures during the years $2012-2017^{2}$. Concerning VC, we collected data from Italian-based (independent) venture capital funds, since marginal investments derive from Corporate Venture Capital. As for the AG, we collected data from Italian-based Angel Groups which mainly belong to the Italian Business Angel Network (IBAN) - the Italian representative association for angel groups

\footnotetext{
2 updated to $18 / 06 / 2017$

Cavallo et al., (2019). Fostering Digital Entrepreneurship from startup to scaleup: The role of 
part of the wider European organization: EBAN (European Business Angels Network). We focused on angel groups for a twofold reason: first, angel grouping is a growing trend in venture financing but still underdeveloped in the entrepreneurial finance literature; second, focusing on angel groups has been considered a valid solution to cope with the issue of identification typically characterizing (individual) angel investors (Harrison and Mason, 1992, Carpentier and Suret, 2015) incline to keep an anonymous profile.

From the original dataset, incomplete rounds were discarded, and then, we selected only those firm operating in the digital sector, and, aged between 1 to 5 years - the latter criterion being introduced in order to focus only on young firms, following Puri and Zarutskie (2012). Finally, in order to isolate the direct impact of venture capital funds and angel groups, we discarded also rounds in which both typologies of investors were involved. Thus, the final database that informed our investigation includes 372 rounds regarding 256 digital new ventures. Among the 256 digital new ventures considered, 200 are only in startup phase, 44 only in scaleup and a portion (12) are first in startup phase to then move intro scaleup phase during the time-span considered. Figure 1 shows the geographical distribution of the digital new ventures in NUTS $3^{3}$. Digital new ventures operate in several business fields. Considering our sample, almost $70 \%$ of the digital new ventures are involved in knowledge intensive business services such as information and communication services and professional, scientific and technical activities. More importantly, the digital ventures combine elements from very different industries: for instance, new venture developing software application for buildings security are digital new ventures offering their products to "buildings" sector, or carsharing company are digital ventures but offering a product in the transport industry.

\footnotetext{
${ }^{3}$ NUTS stands for Nomenclature of Units for Territorial Statistics, geographical nomenclature subdividing the economic territory of the European Union (EU) into regions at three different levels: NUTS 1, 2 and 3 respectively, moving from larger to smaller territorial units. (Source EUROSTAT)
} 


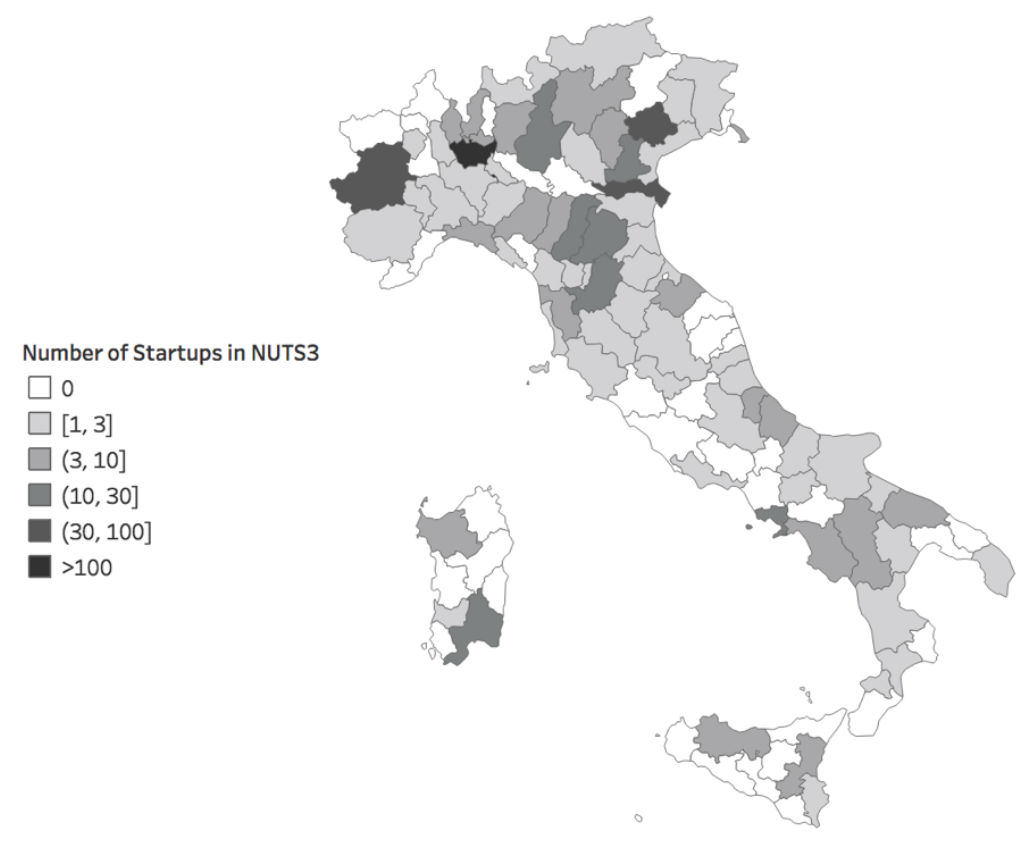

Figure 1. Distribution of digital new ventures in NUTS 3

In addition, we were able to identify and distinguish digital startups from digital scaleups. Indeed, based on the argumentation provided in Section 2.1, we have considered as digital scaleups those new ventures that already had received funding equal or over 1 million $\$$ (Series ' $A$ '), that are approaching the scaling phase; while the remaining new ventures - not yet funded with a Series 'A' - were considered as digital startups. These two initial stages of the digital venture growth - startup and scaleups - are commonly believed as the most critical phases, thus underlining the relevance of this study. Moreover, while recognizing the heterogeneous nature of firm growth (Delmar et al., 2003), it is noteworthy to highlight that we focus on organic growth, since it results more idiosyncratic of smaller and younger firms as our sample refers (Delmar and Shane, 2003; Penrose, 1959).

\subsection{Data gathering}

Data were collected from both Venture Capital (VC) funds and angel groups (AG) through annual surveys from 2012 to 2017 . Over the time-span considered, 29 venture capital funds and 25 angel groups participated to the surveys. A two-wave survey each year - in the time span aforementioned - was carried out to enhance the respondent rate. As regard, were able to reach almost $98 \%$ respondent rate, since the project encountered the institutional support of the Italian Ministry of Economic 
Development and the collaboration with two important Italian association (Italia Startup and Italian Business Angel Network). Indeed, these surveys were part of a permanent project ${ }^{4}$ aimed at monitoring the entrepreneurial ecosystem and investment dynamics in Italy, which received international diffusion and recognition (Kauffman Foundation, 2014). Thus, the data collected are not random sample but are representative of the entire population of investment rounds in the time span considered and aforementioned provided by AG and VC.

Initially, we conducted a pilot survey with five investment organizations based in Milan and operating predominately in Italy to help refine the phraseology of questions before finalizing the data collection process. In the end, minor (wording) changes resulted on original questions. The questionnaire for this study comprised three sections with both closed- and open-ended questions. The questionnaire included a screening question ("Does your organization invest in exchange for equity? Or you provide other forms of financing (e.g. debit)?"), descriptive question to identify the investment organization (VC funds and angels group) and questions on the financing rounds provided to Italian digital new ventures (such as amount, date of investment etc.). Finally, additional financial data regarding the all sample of digital new ventures were collected from secondary sources (such as the Italian Chamber of Commerce Firms Register).

\subsection{Variables}

The literature provides several indicators to measure growth. While subjective satisfaction measures of growth (e.g. Gupta and Govinrandja, 1984) have been largely criticized and as a result are rarely used (Chandler and Hanks, 1993), scholars most commonly use data on employees or sales to measure growth (Delmar, 2006). However, changes in terms of employee certifies the growth (or shrink) of a new venture when it is already consolidated following the increasing demand and sales (Delmar, 2006). Since in this study we focus on digital new ventures in their early stages of growth - i.e. startup and scaleup - Revenues Growth $(R G)$ has been considered as the measure of growth, and hence, it represents our dependent variable. Specifically, RG has been operationalized by comparing the revenue in the year in which the round is executed $(\mathrm{t})$ with the revenue of the previous year $(\mathrm{t}-1)$.

As independent variables, we have considered the amount venture capital investment provided by VC funds (VC) and the amount of venture capital investment provided by angel groups (AG).

\footnotetext{
${ }^{4}$ The permanent project's name was removed from this first submission to ensure anonymity in the reviewing process. Cavallo et al., (2019). Fostering Digital Entrepreneurship from startup to scaleup: The role of 16 Venture Capital funds and Angel Groups
} 
Moreover, we introduced a dummy variable in order to distinguish between digital startups and digital scaleups which assumes 1 when the new venture had ever raised equity equal to or higher than 1 million $\$$ throughout its history (i.e. scaleup), or 0 if not (i.e. startups).

Considering that rounds are autonomously analyzed, some control variables are included in the model in order to control other factors potentially influencing new ventures' growth: Digital Venture (progressive number of new venture in the database), Digital Venture Age (numbers of years from the year of birth), Industry (based on ATECO 5 codes) and Location (based on NUTS $2^{6}$ regions) of the new ventures, Cumulated Capitals (cumulated amount of all the investments received since new venture birth), Previous Revenues (new venture's revenue in the year before the round year) and Round Number (the number of round/s that the new venture received before the round considered). Moreover, other control variables are added to control the round characteristics: Year (year in which the round is done) and Number of Investors (numbers of investors in the round). Table A summarized the variables included in the analysis.

Table A. Variables descriptions

\footnotetext{
5 National version of the European nomenclature, NACE Rev. 2, published in the Official Journal of 20 December 2006 (Regulation (EC) no 1893/2006 of the European Parliament and of the Council of 20 December 2006).

${ }^{6}$ NUTS 2 has been chosen as control to include the influence of localization (e.g Bertoni and Martí). 


\begin{tabular}{|c|c|c|}
\hline Variable & Code & $\begin{array}{c}\text { Definition } \\
\text { [Measurement unit] }\end{array}$ \\
\hline \multicolumn{3}{|c|}{ DEPENDENT VARIABLE } \\
\hline Revenues Growth & $R G$ & Revenue $(t)-$ Revenue $(t-1)[\epsilon]$ \\
\hline \multicolumn{3}{|c|}{ INDEPENDENT VARIABLES } \\
\hline Venture Capital & $V C$ & $\begin{array}{l}\text { Amount of investment provided by } V C \text { funds in a } \\
\text { single round }[€]\end{array}$ \\
\hline Angel Groups & $A G$ & $\begin{array}{l}\text { Amount of investment provided by Angel groups in a } \\
\text { single round [€] }\end{array}$ \\
\hline \multicolumn{3}{|l|}{ CONTROL VARIABLES } \\
\hline Digital Venture & $D V$ & Progressive number of new venture in the databased \\
\hline Digital Venture Age & $D V A$ & Numbers of years since the year of birth [year] \\
\hline Year & $Y$ & Time in which the round is performed [year] \\
\hline Number of Investors & $N I$ & Numbers of investors in the round \\
\hline Round Number & $R N$ & $\begin{array}{l}\text { Number of rounds that the new venture received } \\
\text { before the considered round }\end{array}$ \\
\hline Cumulated Capitals & $C C$ & $\begin{array}{l}\text { Sum of money of all the investments from new } \\
\text { venture birth }[€]\end{array}$ \\
\hline Previous Revenues & $P R$ & Revenue $(t-1)[\epsilon]$ \\
\hline Location & $L O C$ & New venture location in Italian NUTS2 Regions \\
\hline Industry & $I N D$ & New venture industry (ATECO/NACE) \\
\hline
\end{tabular}

Table B provides the descriptive statistics and bivariate correlation matrix for the variables included in the analysis.

Table B. Means, standard deviations and correlations

** Correlation is significant at the 0.01 level (2-tailed). * Correlation is significant at the 0.05 level (2-tailed).

\begin{tabular}{|c|c|c|c|c|c|c|c|c|c|c|c|c|c|c|}
\hline & $\begin{array}{l}\text { Ave } \\
\text { rage }\end{array}$ & $\begin{array}{l}\text { Standar } \\
d \\
\text { Deviatio } \\
n\end{array}$ & RG & VC & $\mathbf{A G}$ & DV & $\begin{array}{c}\text { DV } \\
\text { A }\end{array}$ & $\mathbf{Y}$ & I & RN & $\mathrm{CC}$ & PR & $\begin{array}{c}\text { LO } \\
\text { C }\end{array}$ & IND \\
\hline RG & $\begin{array}{c}10043 \\
1,99\end{array}$ & 349163,41 & 1,000 & & & & & & & & & & & \\
\hline
\end{tabular}




\begin{tabular}{|c|c|c|c|c|c|c|c|c|c|c|c|c|c|c|}
\hline VC & $\begin{array}{c}38452 \\
3,43\end{array}$ & 1411041,31 & $\begin{array}{c}, 700 * \\
*\end{array}$ & $\begin{array}{c}1,00 \\
0\end{array}$ & & & & & & & & & & \\
\hline AG & $\begin{array}{c}21245 \\
2,96\end{array}$ & 586156,90 & 0,013 & $\begin{array}{l}(0,0 \\
99)\end{array}$ & $\begin{array}{c}1,00 \\
0\end{array}$ & & & & & & & & & \\
\hline DV & $\begin{array}{c}262,4 \\
7\end{array}$ & 147,08 & $\begin{array}{c}(0,12 \\
8)^{*}\end{array}$ & $\begin{array}{c}- \\
0,10 \\
1\end{array}$ & $\begin{array}{c}- \\
0,05 \\
4\end{array}$ & $\begin{array}{c}1,00 \\
0\end{array}$ & & & & & & & & \\
\hline DVA & 1,00 & 1,05 & $\begin{array}{l}(0,23 \\
4)^{* *}\end{array}$ & $\begin{array}{l}0,18 \\
9^{* *}\end{array}$ & $\begin{array}{c}0,12 \\
8^{*}\end{array}$ & $\begin{array}{c}(0,04 \\
6)\end{array}$ & $\begin{array}{c}1,00 \\
0\end{array}$ & & & & & & & \\
\hline $\mathbf{Y}$ & $\begin{array}{c}2013 \\
72\end{array}$ & 1,04 & 0,065 & $\begin{array}{l}(0,0 \\
12)\end{array}$ & $\begin{array}{c}163 \\
* *\end{array}$ & $\begin{array}{c}0,06 \\
9\end{array}$ & $\begin{array}{l}0,37 \\
9 * *\end{array}$ & $\begin{array}{c}1,00 \\
0\end{array}$ & & & & & & \\
\hline NI & 1,88 & 10,19 & $\begin{array}{c}(0,01 \\
4)\end{array}$ & $\begin{array}{l}(0,0 \\
11)\end{array}$ & $\begin{array}{l}, 273 \\
* *\end{array}$ & $\begin{array}{c}(0,05 \\
7)\end{array}$ & $\begin{array}{c}0,05 \\
9\end{array}$ & $\begin{array}{c}0,07 \\
1\end{array}$ & $\begin{array}{c}1,00 \\
0\end{array}$ & & & & & \\
\hline $\mathbf{R N}$ & 0,99 & 1,34 & $\begin{array}{c}0,178 \\
* *\end{array}$ & $\begin{array}{c}0,13 \\
0^{*}\end{array}$ & $\begin{array}{c}0,02 \\
7\end{array}$ & $\begin{array}{c}(0,00 \\
9)\end{array}$ & $\begin{array}{l}0,43 \\
9^{* *}\end{array}$ & $\begin{array}{l}0,26 \\
2^{* *}\end{array}$ & $\begin{array}{c}(0,02 \\
9)\end{array}$ & $\begin{array}{c}1,00 \\
0\end{array}$ & & & & \\
\hline $\mathrm{CC}$ & $\begin{array}{c}60263 \\
5,58\end{array}$ & 2130736,63 & $\begin{array}{c}0,688 \\
* *\end{array}$ & $\begin{array}{l}0,78 \\
8^{* *}\end{array}$ & $\begin{array}{c}0,02 \\
5\end{array}$ & $\begin{array}{c}(0,08 \\
6)\end{array}$ & $\begin{array}{l}0,33 \\
7 * *\end{array}$ & $\begin{array}{c}0,06 \\
1\end{array}$ & $\begin{array}{c}(0,00 \\
8)\end{array}$ & $\begin{array}{l}0,39 \\
4 * *\end{array}$ & $\begin{array}{c}1,00 \\
0\end{array}$ & & & \\
\hline PR & $\begin{array}{c}85946 \\
, 94\end{array}$ & 462761,68 & $\begin{array}{c}0,580 \\
* *\end{array}$ & $\begin{array}{l}0,57 \\
4^{* *}\end{array}$ & $\begin{array}{c}0,05 \\
4\end{array}$ & $\begin{array}{c}(0,03 \\
0)\end{array}$ & $\begin{array}{l}0,24 \\
7 * *\end{array}$ & $\begin{array}{c}0,10 \\
7^{*}\end{array}$ & $\begin{array}{c}(0,00 \\
8)\end{array}$ & $\begin{array}{c}0,11 \\
1^{*}\end{array}$ & $\begin{array}{l}0,66 \\
8^{* *}\end{array}$ & $\begin{array}{c}1,00 \\
0\end{array}$ & & \\
\hline LOC & 5,13 & 4,51 & 0,034 & $\begin{array}{c}0,04 \\
0\end{array}$ & $\begin{array}{c}(0,00 \\
8)\end{array}$ & $\begin{array}{c}(0,03 \\
1)\end{array}$ & $\begin{array}{c}0,01 \\
0\end{array}$ & $\begin{array}{c}(0,04 \\
5)\end{array}$ & $\begin{array}{c}(0,00 \\
7)\end{array}$ & $\begin{array}{c}(0,01 \\
0)\end{array}$ & $\begin{array}{c}0,03 \\
2\end{array}$ & $\begin{array}{c}0,07 \\
2\end{array}$ & $\begin{array}{c}1,00 \\
0\end{array}$ & \\
\hline IND & 59,06 & 13,03 & $\begin{array}{c}(0,06 \\
2)\end{array}$ & $\begin{array}{l}(0,0 \\
26)\end{array}$ & $\begin{array}{c}0,01 \\
4\end{array}$ & $\begin{array}{c}0,06 \\
9\end{array}$ & $\begin{array}{c}(0,08 \\
0)\end{array}$ & $\begin{array}{c}(0,03 \\
6)\end{array}$ & $\begin{array}{c}0,01 \\
3\end{array}$ & $\begin{array}{c}(0,01 \\
7)\end{array}$ & $\begin{array}{c}0,02 \\
0\end{array}$ & $\begin{array}{c}(0,04 \\
2)\end{array}$ & $\begin{array}{c}(0,02 \\
6)\end{array}$ & $\begin{array}{c}1,00 \\
0\end{array}$ \\
\hline
\end{tabular}

\section{RESULTS}

The results of the linear regression models predicting the Revenues Growth of the digital ventures are shown in Table C, which reports the following two models: Model 1.I represents the baseline model and includes all the control variables; Model 1.II includes also the independent variables about the amount of investments received by digital ventures in order to test hypotheses H1.1 and H1.2. 
Table C. Regression Model predicting Revenues Growth of digital ventures (H1.1 and H1.2)

\begin{tabular}{lcrrr}
\hline Digital New Ventures & Model 1.I & Model 1.II \\
& Coefficient & T-Stat. & Coefficient & \multicolumn{1}{c}{ T- } \\
& & & & Stat. \\
\hline VC & - & - & $0.399^{* * *}$ & 6.482 \\
AG & - & - & 0.032 & 0.856 \\
CC & $0.589^{* * *}$ & 10.461 & $0.250^{* * *}$ & 3.347 \\
NI & $(0.016)$ & 0.442 & $(0.021)$ & 0.581 \\
Y & 0.033 & 0.815 & 0.032 & 0.819 \\
DV & $(0.070)$ & 1.888 & $(0.059)$ & 1.662 \\
RN & $(0.090)^{*}$ & 1.995 & $(0.010)$ & 0.230 \\
DVA & 0.009 & 0.190 & 0.015 & 0.355 \\
PR & $0.187^{* * *}$ & 3.591 & $0.173^{* * *}$ & 3.514 \\
IND & $(0.059)$ & 1.581 & $(0.042)$ & 1.192 \\
LOC & $(0.001)$ & 0.030 & $(0.003)$ & 0.090 \\
\hline$R^{2}$ & 0.515 & & 0.566 & \\
Adj $R^{2}$ & 0.502 & & 0.553 & \\
\hline
\end{tabular}

Structural estimates (*: $p<0.05 ; * *: p<0.01 ; * * *: p<0.001)$.

The empirical results described by Model 1.I show as significant controls the following variables: Digital Venture, Round Number, Cumulated Capitals and Previous Revenues. Hypothesis H1.1 predicts that the amount of venture capital investments provided by VC funds (VC) positively impacts on the Revenues Growth of digital ventures, while Hypothesis H1.2 predicts that the amount of venture capital investments provided by Angel Groups (AG) positively impacts on the Revenues Growth of digital ventures. Model 1.II includes both $V C$ and $A G$ investments, but only the first one shows a significant coefficient (Beta $=+0,399$; $\mathrm{p}$-value $<0,001)$ supporting the Hypothesis H1.1. The empirical results do not support the Hypothesis H1.2 showing that $A G$ investments doesn't impact on Revenues Growth (Beta $=+0,032 ; \mathrm{p}-$ value $>0,1)$.

In order to investigate potential different relationships along the digital venture growth path introduced in the theoretical background, Tables D and E report similar analyses focusing separately Cavallo et al., (2019). Fostering Digital Entrepreneurship from startup to scaleup: The role of 20 Venture Capital funds and Angel Groups 
on digital startups and scaleups. More specifically Table D relies only on investment rounds received by startups and reports the empirical results about the following three models: Model 2.I represents the baseline model and includes all the control variables; Model 2.II includes also the independent variables about the amount of $V C$ and $A G$ investments received by digital startups in order to test hypotheses H2.1 and H2.2; Model 2.III considers also squared effects of $V C$ and $A G$ investments in order to test an inverted U-shaped relationship with Revenues Growth.

Table D. Regression Model predicting Revenues Growth of digital startups (H2.1 and H2.2)

\begin{tabular}{|c|c|c|c|c|c|c|}
\hline \multirow{2}{*}{$\begin{array}{l}\text { Digital } \\
\text { Startups }\end{array}$} & \multicolumn{2}{|c|}{ Model 2.I } & \multicolumn{2}{|c|}{ Model 2.II } & \multicolumn{2}{|c|}{ Model 2.III } \\
\hline & $\begin{array}{c}\text { Coefficien } \\
t\end{array}$ & $T-$ Stat. & Coefficient & T-Stat. & $\begin{array}{c}\text { Coefficien } \\
t\end{array}$ & T-Stat. \\
\hline $\mathrm{VC}$ & - & - & $0.157^{*}$ & 2.434 & $0.489^{*}$ & 2.186 \\
\hline$A G$ & - & - & 0.101 & 1.530 & $(0.283)$ & 1.484 \\
\hline $\mathrm{CC}$ & $0.369 * * *$ & 3.666 & $0.263^{*}$ & 2.398 & $0.216^{*}$ & 1.981 \\
\hline NI & (0.019) & 0.335 & $(0.021)$ & 0.384 & 0.001 & 0.018 \\
\hline Y & 0.108 & 1.793 & 0.105 & 1.760 & 0.114 & 1.931 \\
\hline DV & (0.009) & 0.166 & $(0.011)$ & 0.190 & 0.005 & 0.093 \\
\hline $\mathrm{RN}$ & $(0.264) * *$ & 2.584 & $(0.180)$ & 1.683 & $(0.148)$ & 1.396 \\
\hline DVA & $0.154^{*}$ & 2.461 & 0.118 & 1.839 & 0.115 & 1.826 \\
\hline $\mathrm{PR}$ & $(0.091)$ & 1.623 & $(0.087)$ & 1.564 & $(0.091)$ & 1.658 \\
\hline IND & $(0.163)^{*}$ & 2.912 & $(0.168)^{* *}$ & 2.999 & $(0.168)^{* *}$ & 3.046 \\
\hline LOC & $(0.082)$ & 1.479 & $(0.102)$ & 1.829 & $(0.100)$ & 1.822 \\
\hline $\mathrm{VC}^{2}$ & - & - & - & - & $(0.387)^{*}$ & 2.335 \\
\hline $\mathrm{AG}^{2}$ & - & - & - & - & 0.414 & 1.852 \\
\hline$R^{2}$ & \multicolumn{2}{|c|}{0.144} & \multicolumn{2}{|c|}{0.162} & \multicolumn{2}{|c|}{0.195} \\
\hline Adj. R2 & \multicolumn{2}{|c|}{0.117} & \multicolumn{2}{|c|}{0.130} & \multicolumn{2}{|c|}{0.157} \\
\hline
\end{tabular}

Structural estimates (*: $p<0.05$; **: $p<0.01 ; * * *: p<0.001)$.

The empirical results described by Model 2.I show as significant controls the following variables: Digital Venture (Start-up) Age, Round Number, Cumulated Capitals and Industry. According to Hypothesis $\mathrm{H} 2.1$ the amount of $V C$ investments positively impacts on the Revenues Growth of digital startups; symmetrically Hypothesis $\mathrm{H} 2.2$ posits that the amount of $A G$ investments positively impacts on the Revenues Growth of digital startups. Model 2.II includes both $V C$ and $A G$ investments, but, similarly to the empirical results reported by Model 1.II, only the first one shows a significant Cavallo et al., (2019). Fostering Digital Entrepreneurship from startup to scaleup: The role of 21 Venture Capital funds and Angel Groups 
coefficient $($ Beta $=+0,157$; $\mathrm{p}$-value $<0,05)$. The empirical results do not support the Hypothesis H2.2 showing that $A G$ investments doesn't impact on Revenues Growth (Beta $=+0,101$; $\mathrm{p}$-value $>$ 0,1). Even if the empirical results about digital startups appear aligned with the ones about digital ventures, the lower value about $\mathrm{R}^{2}(0,162)$ about digital startups vs 0,195 about digital ventures) suggests us to explore additional models. For this reason, Model 2.III considers both linear and squared effects of $V C$ and $A G$ investments on Revenues Growth. The empirical results show that an inverted U-shaped relationship exists between $V C$ investments and Revenues Growth of digital startups; more specifically both the linear and the squared effects show significant coefficients (Beta $=+0,489 ; \mathrm{p}$-value $<0,1$ about the linear effect; Beta $=-0,387 ; \mathrm{p}$-value $<0,1$ about the squared effect). As a robustness check, we tested if an inverted U-shaped relationship exists between $V C$ investments and Revenues Growth of digital ventures, but the squared effect is not significant (see Appendix 1 reporting Model 1.III).

Table E relies only on investment rounds received by scaleups and reports the empirical results about the following two models: Model 3.I represents the baseline model and includes all the control variables; Model 3.II includes also the independent variables about the amount of $V C$ and $A G$ investments received by digital scaleups in order to test hypotheses H3.1 and H3.2.

Table E. Regression Model predicting Revenues Growth of digital scaleups (H3.1 and H3.2)

\begin{tabular}{lcrrr}
\hline $\begin{array}{l}\text { Digital } \\
\text { Scaleups }\end{array}$ & Model 3.I & \multicolumn{3}{c}{ Model 3.II } \\
& Coefficient & T-Stat. & Coefficient & T-Stat. \\
\hline VC & - & - & $0.431^{* *}$ & 2.935 \\
AG & - & - & 0.035 & 0.387 \\
CC & $0.624^{* *}$ & 3.975 & 0.174 & 0.821 \\
NI & $(0.032)$ & 0.385 & $(0.024)$ & 0.298 \\
Y & $(0.007)$ & 0.070 & $(0.012)$ & 0.127 \\
DV & $(0.126)$ & 1.408 & $(0.149)$ & 1.742 \\
RN & $(0.155)$ & 1.160 & 0.013 & 0.094 \\
DVA & $(0.032)$ & 0.263 & 0.010 & 0.082 \\
PR & 0.238 & 1.792 & $0.258^{*}$ & 2.054 \\
IND & $(0.005)$ & 0.058 & 0.026 & 0.318 \\
LOC & 0.074 & 0.891 & 0.074 & 0.937 \\
\hline$R^{2}$ & 0.601 & & 0.653 & \\
Adj. $R 2$ & 0.543 & & 0.590 & \\
\hline
\end{tabular}

Structural estimates (*: $p<0.05 ; * *: p<0.01 ; * * *: p<0.001)$. 
The empirical results described by Model 3.I show as significant control: Cumulated Capitals Hypothesis H3.1 predicts that the amount of VC investments positively impacts on the Revenues Growth of digital scaleups, while Hypothesis H3.2 predicts that the amount of $A G$ investments positively impacts on the Revenues Growth of digital scaleups. Model 3.II includes both $V C$ and $A G$ investments, but only the first one shows a significant coefficient $($ Beta $=+0,431 ; \mathrm{p}$-value $<0,01)$ supporting the Hypothesis H3.1. The empirical results don't support the Hypothesis H3.2 showing that $A G$ investment doesn't impact on Revenues Growth (Beta $=+0,035 ; \mathrm{p}$-value $>0,1)$. As a robustness check, we tested if an inverted U-shaped relationship exists between $V C$ investments and Revenues Growth of digital scaleups, but the squared effect is not significant (see Appendix 1 reporting Model 3.III).

\section{DISCUSSION}

In this section, we analyze and discuss how different venture capital (VC) funds and angel groups affect the growth of digital new ventures.

In accordance with Hellmann and Thiele (2015), our analysis reveals that angel groups and VC funds are partially overlapped in their action space of investment, specifically in the range from $\$ 10.000$ to $\$ 8$ millions. This finding, confirms that by means of resource pooling angels may invest larger amounts while VC funds are moving into earlier stages than in the past (Dutta and Folta, 2016). However, this evidence is not informative about the possible benefits for digital new venture growth stemming from this rather substitutable role of angel groups and VC funds.

Hence, we examined the growth path (in terms of revenues) of digital new ventures that received funding from angel groups and those who received funding from $\mathrm{VC}$ funds. We find evidence of a significant and positive impact of VC on digital new venture growth while no evidence describes how angel groups affect digital new venture growth. As result, hypothesis H1.1 has been confirmed while H1.2 is not supported. Similarly to our results, Dutta and Folta (2016) find greater impact on (innovative) performance provided by VC-backed rather than angel group-backed. The literature offered several contributions showing that VC-backed, while operating in uncertainty (Venkataraman, 1997), have higher average growth rates if compared with no VC-backed (Davila et al., 2003). Scholars also provided multiple rationales explaining why this happen: for instance, due to the active role played by $\mathrm{VC}$, providing managerial knowledge, expertise and network of contacts (Sapienza and Gupta, 1994). Fewer studies have investigated how angels may affect new venture 
growth (Croce et al., 2018), and even less attention was paid to the emerging phenomenon of angel grouping. For instance, Kerr et al. (2011) find evidence of a positive impact of angel groups on new venture performance and growth. However, Kerr et al. (2011) and other scholars (May, 2002; Payne and Macarty, 2002) focus on few selected angel groups rather than being inclusive. By focusing on a larger sample of angel groups, our results show that angel groups are less effective than VC in sustaining new venture growth. This result has a number of possible explanations.

According to the literature, by pooling their resources, angel groups have more financial firepower and should be more efficient since they can afford a more structured deal screening process (May, 2002; Kerr et al., 2011). However, several angel groups similarly to independent angels tend to rely more on intuition and trust rather than a formal due diligence process (Galbraith et al., 2009). For instance, some angel groups still do not employ a committee of members to perform the initial screening of submitted business plans (Galbraith et al., 2009). This reveals the heterogeneous and still informal nature of angel groups that may affect their overall impact on digital new venture growth. Valuable contributions had been focused on heterogeneity among individual angels (see for instance, Freear et al., 1994), while fewer studies focused on angel groups heterogeneity. As regard, Payne and Macarty (2002) provide a distinction between the more informal angel network and the more formal angel fund. Future research should also take into account the heterogeneity nature of angel groups. A further interpretation lies on the arguably recent nature of the angel grouping in Italy and more in general in Europe if compared with US. On this metter, recently, Lerner et al. $(2018$, p.2) argue that "in countries lacking the culture and infrastructure to support startup investment, angels only waste their time and money with no real impact". One possible explanation is that this new form of venture financing needs to find its best organization and it needs time and experience before to make an impact on a larger scale (May, 2002).

Beside analyzing digital new venture growth toward the impact of two different type of investors (angel groups and VC funds), this study provides further evidence on two different and specific stages of digital new venture growth: startup and scaleup. Based on the emerging model of digital new venture growth, we analyze how venture financing explains digital startup and digital scaleup growth. Interesting results emerged considering how VC affect digital scaleup (H2.1) and (more importantly) digital startup growth (H3.1), while no significant evidence relay on angel groups' impact (H2.2 and H3.2). Specifically, the magnitude effect of the VC funds on the two stages are considerably different. The VC funds lead to more substantial growth of digital scaleup than startups. Moreover, the digital scaleups growth presents a linear and positive correlation with the amount of funding received from VC, thus confirming H3.1. While, more interestingly, a peculiar and different shape characterizes Cavallo et al., (2019). Fostering Digital Entrepreneurship from startup to scaleup: The role of 24 Venture Capital funds and Angel Groups 
digital startups. Contrarily to our expectation (H2.1), as the amount of funding increased, digital startups - grew at first, and then decreased after an optimal level of 300,000\$. Valuable insights may emerge by interpreting the digital startup growth path and by comparing it with the digital scaleups growth trend. A first potential explanation we provide is grounded on the entrepreneurial bias literature. A bias is a systematic deviation from a rational choice during a decision-making process (Baron, 2007; Zhang and Cueto, 2017). According to Busenitz and Barney (1997), entrepreneurs display a higher level of bias than managers in larger organizations. Since its inception, the concept of bias has been widely researched and became an important area of investigation within the entrepreneurship field (Zhang and Cueto, 2017). Bias in decision making process is originated by overconfidence and over-optimism. Overconfidence may have an initial positive effect increasing the motivation to initiate entrepreneurial action (Simon and Shrader, 2012) but soon after a negative effect may occur affecting the growth and ultimately the survival of a new ventures. This is in line with the growth path followed by digital startups in our study. Moreover, some scholars argue that overconfidence - and specifically its negative effect on performance - may arise specifically for funders who obtain a first significant amount of external financing (Tyebjee and Bruno, 1984; Hayward et al., 2006), which in our study and sample is represented by the optimal value of 300,000\$. Empirical studies confirm that overconfidence may prolong entrepreneurs' unsuccessful development efforts leading to waste of financial resources, thus affecting economic (revenue) and organizational (headcount) growth (Lowe and Ziedonis, 2006). Hence, a first explanation of our finding is that funders of digital startups, due to overconfidence issue, may manage improperly additional funding, leading to a decrease of performance and growth rates. As additional explanation, it may result that digital startups over the optimal value of $300,000 \$$ are in need of a substantial higher investment round in order to scale. Those new ventures that continue to receive investment rounds but not as much to become scaleups ( $>=1 \mathrm{Mln} \$$ ) prolong their startup phase. As result, funders have to delay their growth because of lack of sufficient funds. Since the strategy of hi-tech (thus digital) new ventures often relies on a timely execution, delayed execution may negatively affect the ability of the startup to grow and be successful (Davila et al. 2003).

Digital startups may fail in obtaining funds over \$ 1 million for several reasons. Realistically, several scholars and policy makers acknowledge that the venture capital market in EU is still characterized by an equity gap, with particular reference to especially southern European countries (Harding and Pagan, 2002; EVCA, 2016). Indeed, although angel grouping may contribute to bridging to lower end the equity gap, imbalance between demand and supply of funding remains (Freear et al., 2002). Moving from system level to individual or firm level, intrinsic problems emerging during the venture 
development process may affect funders' ability to persuade investors for a further significant round (over 1 million \$). Moreover, overconfident funders' - after receiving a significant amount of funding (300,000\$ in our sample) - may overvalue their ventures, thus impeding to obtain a larger investment (Hayward et al., 2006).

Since overconfidence may have such dominant impact on digital scaleups, one might argue that overconfidence should affect also digital startups. As regard, borrowing from Hayward et al. (2006) we argue that declines in overconfidence occur when funders become more skilled, and accumulate more experience. This interpretation is in line with and further supports the emerging model of organization growth where digital scaleup (already funded through a first Series 'A' round - over 1 million \$) are considered in a later stage of maturity compared to digital startups (Parker et al., 2016; Marmer et al., 2011). The earlier stages are always characterized by greater level of uncertainty and complexity when compared with later stages. Building on Hayward et al. (2006), greater effect from overconfidence in the startup stage since greater is the level of complexity and uncertainty.

Entrepreneurial bias properly serves as an "entrepreneur-centric" lens while analyzing growth path of new ventures. Scholars recognize that entrepreneurs are still a dominant agent also in digital entrepreneurship (Nambisan, 2017). While, in this study, we are consistent with this view, we deem important also to take a broader and "eco-system" perspective when analyzing digital entrepreneurship (Autio et al., 2018). Indeed, digital entrepreneurs are supported by an increasing number of players and actors towards a collective way of pursuing entrepreneurship (Srinivasan and Venkatraman, 2018; Shah and Tripsas 2007). Besides, our main result shows that VC funds still have a strong influence on digital new venture growth, with specific reference to the scaleup phase. This result may suggest that when the digital new venture reaches a certain level of maturity (i.e. scaleup, by having a validated value offering), $\mathrm{VC}$ and related funding play a major role in growth. By contrast, in earlier and startup phase, VC has a non-linear and U-shape effect on digital startup growth. This result appears consistent with a main argument in digital entrepreneurship literature which emphasizes how digital technologies are leading to an increased unpredictability and non-linearity of new ventures growth (Huang et al., 2017; Nambisan, 2017). In addition, the non-linear and Ushape effect on digital startup growth may inform about other agents' influence in entrepreneurial process, such as, for instance, customers. By providing new ventures with an initial seed funding, VC can boost early growth of digital startups; then, if entrepreneurs do not find a market willing to adopt their solution and provide feedbacks that feed a learning and improving process, growth will inevitably slow down. Customers are indeed crucial agents, especially in the early phase of digital Cavallo et al., (2019). Fostering Digital Entrepreneurship from startup to scaleup: The role of 26 Venture Capital funds and Angel Groups 
entrepreneurship, which typically leverages experimental approaches to build a validated entrepreneurial outcome, in the form of a business model (Ghezzi and Cavallo, 2018), ready to enter the scaling phase. As in accordance with recent contributions, digital startups are typically focused on testing and validating their business model, while digital scaleups already show traction on customers and a validated business model (Autio, 2016). While offering a first potential explanation over the different influence VC may play on startup and scaleup phase, based on recent research developments in digital entrepreneurship, we believe there is room for further studies which should deepen the investigation on the influence $\mathrm{VC}$, angels, customers and other agents gravitating around digital new ventures may have in different phases of their growth path.

\section{CONCLUSION}

This study has explored the role of venture capital (VC) funds and angel groups in explaining digital new ventures growth, with particular reference to two different stages: startup and scaleup. A sample of 256 Italian digital new ventures funded by VC funds and angel groups (over the time-span 20122017) informed our investigation. Our findings suggest that VC funds positively affect the growth of digital new ventures while no evidence emerges on the angel groups contribution. Moreover, by focusing on digital startup and digital scaleups - as two distinct stages of growth of digital new ventures - and related subsamples, two additional insights emerge from this study. First, digital scaleups, in line with the overall sample of digital new ventures, show a linear path of growth positively correlated with VC funding. Second, and in contrast to our expectation, digital startups as the amount of funding increased - at first grew and then decreased after an optimal level of $300,000 \$$.

This study provides interesting addition on the current debate on digital entrepreneurship. By leveraging entrepreneurial bias as theoretical lens, we were able to interpret our results from an "entrepreneur-centric" perspective. In accordance with other scholars, we recognize how an individual perspective is still relevant, even in digital entrepreneurship where more agents are usually involved in the entrepreneurial process. In parallel, we remarked the relevance of analyzing digital entrepreneurship with a broader and "ecosystem" perspective. A combination of individual and ecosystem views, indeed, may serve as complementary lenses while focusing on digital entrepreneurship across the growth phases. Our study contributes to the current debate on 
entrepreneurial agency as a distinctive feature of digital entrepreneurship by showing that, in scaleup phase, $\mathrm{VC}$ are a major agent influencing growth, while in startup phase it is more likely that other agents may play a relevant role. We believe the topic adressed is central and emerging in digital entrepreneurship, thus, future studies should focus on expanding this promising research direction. Furthermore, building on recent contributions (such as Blank, 2013; Huang et al.,2017; Autio et al., 2018) while grounded in the organizational growth literature, our research further develops and conceptualizes the emerging model of digital new venture growth. As regard, we dealt with the fuzzy conceptualization of traction as evidence of a growing demand of the product/services offered to the market. Trying to tackle and operationalize the traction concept can be problematic, since metrics of traction may vary significantly within the digital sector according to the specific product-market addressed by the firm (Onetti, 2014). Researcher may cope with this issue by focusing on digital new ventures entering the scaling phase (by receiving over 1 million $\$$ funding) without regards to detect evidence of traction. According to Delmar (2006), the growing demand is the first stage of new ventures' growth process, which it will consequently lead to higher sales and to hire new employee. Thus, researcher interested in digital new ventures that successfully embraced the scaleup phase may refer to the literature on "gazelles" (Duruflé, et al., 2017; Henrekson and Johansson, 2010).

Research value is also connected to the venture financing literature for a twofold reason. First, due to the empirical setting chosen: Italy. Prior research on venture financing had been mainly focused on US Venture Capital (VC) market and other well-developed market (e.g. UK, Israel). Little attention has been dedicated to other VC markets, though in need of a deeper understanding. This is especially the case for southern European VC market, characterized by a significant imbalance between demand and supply of funding (Freear et al., 2002; Harding and Pagan, 2002; EVCA, 2016). Second, the results of the study contribute to academic understanding of the emerging trends in venture financing and their role in fostering digital entrepreneurship. Specifically, we refer to angel grouping proliferation across the globe and to the growing interest of VC funds in earlier venture stage. Due to their recent emergence, few studies (e.g. Dutta and Folta, 2016) dealt with these two trends and their impact on new venture growth. In particular, the extant literature lacks a focus on angel investment organization or angel groups. Research on angel groups has been mostly based on convenience sample rather than representative of the population (Freear et al., 2002). Indeed, scholars analyzed angel groups while referring on few and virtuous examples (e.g. see Kerr et al., 2011; May, 2002; Payne and Macarty, 2002). Conversely, our study relay on a larger sample of angel groups (25). Hence, extending the generalizability and the relevance of our results. 
This study appears of relevance for a plethora of actors belonging to the wide digital entrepreneurial ecosystem (Autio et al., 2018; Cavallo et al., 2018b) such as entrepreneurs, investors and policy makers. Digital entrepreneurs should be aware of the relative contribution of angel groups and venture capital funds to venture performance and growth. Moreover, our results suggest that after an optimal value of $300,000 \$$ entrepreneurs should seek for larger rounds (over 1 million $\$$ ) in order to scale. Knowing that failing in this task may imply a decrease in performance, thus compromising the firm's survival. In addition, digital entrepreneurs - especially those in startup phase - should be aware of how overconfidence may represent a risk and how it can shape and influence venture performance. Likewise, investors may have to consider the risks related to founders' overconfidence, and, try to mitigate those risks though proper support. Regarding angel groups, this study suggest that they may suffer of experience gap compared to VC funds, thus affecting their contributions to digital new venture growth: this may represent a line of public intervention, as measures supporting angel groups organization should be a main concern for policy makers attempting to foster digital entrepreneurship. This study is not free of limitation. First, our research specifically applies to the digital industry, and it refers to the Italian venture capital market (not yet fully developed, compared to other mature ecosystems like the US one). This context-specific limitation may reduce the generalizability of our results, which leaves room to future studies - for instance, by referring to the broader hi-tech sector. Second, the study focuses on a specific performance such as revenue growth. Even if such performance appears particularly appropriate when analyzing new digital ventures that are going through the startup and scaleup phases, it could be particularly interesting to explore the contribution of VC and AG investments on different growth measures such as EBIT or cash flows. Third, the analysis is limited to the first phases of the digital venture growth path: startup and scaleup (the latter being considered as only those new digital firms entering the scaling phase and not yet considered as gazelles). Extending the investigation by including later stages and by comparing timing and frequency of investments may enrich the reflections presented in this study. Fourth, the tested model includes control variables such as the digital venture's age or the number of investors but other variables such as those on innovative performances were not included. Future researches may enrich our model considering whether the innovative performances of digital new ventures affect the relation between funding and company's growth. Finally, the paper does not disentangle selection versus value-added effects. Future studies may consider other external (e.g. economic and technological) determinants which can influence digital new venture growth. 
This research did not receive any specific grant from funding agencies in the public, commercial, or not-for-profit sectors.

\section{REFERENCE}

Amit, R., Brander, J., \& Zott, C. (1998). Why do venture capital firms exist? theory and canadian evidence. Journal of Business Venturing, 13(6), 441-466.

Audretsch, D. B., \& Lehmann, E. E. (2004). Financing high-tech growth: The role of banks and venture capitalists. Schmalenbach Business Review, 56(4), 340-357.

Autio, E. (2016). Entrepreneurship support in europe: Trends and challenges for EU policy. London, England: Imperial College Business School,

Autio, E., Nambisan, S., Thomas, L. D., \& Wright, M. (2018). Digital affordances, spatial affordances, and the genesis of entrepreneurial ecosystems. Strategic Entrepreneurship Journal, 12(1), 72-95.

Baron, R. A. (2007). Behavioral and cognitive factors in entrepreneurship: Entrepreneurs as the active element in new venture creation. Strategic Entrepreneurship Journal, 1(1-2), 167-182.

Baum, J. A., \& Silverman, B. S. (2004). Picking winners or building them? alliance, intellectual, and human capital as selection criteria in venture financing and performance of biotechnology startups. Journal of Business Venturing, 19(3), 411-436.

Berglof, E. (1994). A control theory of venture capital finance. JL Econ.\& Org., 10, 247.

Bertoni, F., \& Martí, J. (2011). Financing entrepreneurial ventures in Europe: The VICO dataset. Available at SSRN 1904297.

Bertoni, F., Colombo, M. G., \& Grilli, L. (2011). Venture capital financing and the growth of high-tech startups: Disentangling treatment from selection effects. Research Policy, 40(7), 1028-1043.

Birch, D. L., Haggerty, A., \& Parsons, W. (1993). Who's creating jobs? Cognetics.

Blank, S. (2013). The four steps to the epiphany: Successful strategies for products that win BookBaby.

Bruton, G. D., Filatotchev, I., Chahine, S., \& Wright, M. (2010). Governance, ownership structure, and performance of IPO firms: The impact of different types of private equity investors and institutional environments. Strategic Management Journal, 31(5), 491-509.

Bruton, G., Khavul, S., Siegel, D., \& Wright, M. (2015). New financial alternatives in seeding entrepreneurship: Microfinance, crowdfunding, and peer-to-peer innovations. Entrepreneurship Theory and Practice, 39(1), 9-26.

Busenitz, L. W., \& Barney, J. B. (1997). Differences between entrepreneurs and managers in large organizations: Biases and heuristics in strategic decision-making. Journal of Business Venturing, 12(1), 9-30. 
Carpentier, C., \& Suret, J. (2015). Angel group members' decision process and rejection criteria: A longitudinal analysis. Journal of Business Venturing, 30(6), 808-821.

Cavallo, A., Ghezzi, A., Colombelli, A., \& Casali, G. L. (2018a). Agglomeration dynamics of innovative startups in Italy beyond the industrial district era. International Entrepreneurship and Management Journal, $1-24$.

Cavallo, A., Ghezzi, A., \& Balocco, R. (2018b). Entrepreneurial ecosystem research: present debates and future directions. International Entrepreneurship and Management Journal, 1-31.

Chan, Y. (1983). On the positive role of financial intermediation in allocation of venture capital in a market with imperfect information. The Journal of Finance, 38(5), 1543-1568.

Chandler, A. D. (1962). Strategy and structure: Chapters in the history of the american enterprise. Massachusetts Institute of Technology Cambridge, 4(2), 125-137.

Chandler, G. N., \& Hanks, S. H. (1993). Measuring the performance of emerging businesses: A validation study. Journal of Business Venturing, 8(5), 391-408.

Collewaert, V. (2012). Angel investors' and entrepreneurs' intentions to exit their ventures: A conflict perspective. Entrepreneurship Theory and Practice, 36(4), 753-779.

Colombo, M. G., \& Grilli, L. (2005). Founders' human capital and the growth of new technology-based firms: A competence-based view. Research Policy, 34(6), 795-816.

Colombo, M. G., \& Grilli, L. (2010). On growth drivers of high-tech startups: Exploring the role of founders' human capital and venture capital. Journal of Business Venturing, 25(6), 610-626.

Croce, A., Guerini, M., \& Ughetto, E. (2018). Angel financing and the performance of High-Tech Start-Ups. Journal of Small Business Management, 56(2), 208-228.

Cumming, D. (2008). Contracts and exits in venture capital finance. The Review of Financial Studies, 21(5), 1947-1982.

Delmar, F., \& Wiklund, J. (2003). (2003). The effect of the entrepreneur's growth motivation on subsequent growth: A longitudinal study. Paper presented at the Academy of Management Meeting, Seattle, , 72

Delmar, F. (2006). Measuring growth: Methodological considerations and empirical results. Entrepreneurship and the Growth of Firms, 1(1), 62-84.

Delmar, F., \& Shane, S. (2003). Does business planning facilitate the development of new ventures? Strategic Management Journal, 24(12), 1165-1185.

Dimov, D. P., \& Shepherd, D. A. (2005). Human capital theory and venture capital firms: Exploring "home runs" and "strike outs". Journal of Business Venturing, 20(1), 1-21.

Drover, W., Busenitz, L., Matusik, S., Townsend, D., Anglin, A., \& Dushnitsky, G. (2017). A review and road map of entrepreneurial equity financing research: Venture capital, corporate venture capital, angel investment, crowdfunding, and accelerators. Journal of Management, 43(6), 1820-1853.

Dutta, S., \& Folta, T. B. (2016). A comparison of the effect of angels and venture capitalists on innovation and value creation. Journal of Business Venturing, 31(1), 39-54.

Cavallo et al., (2019). Fostering Digital Entrepreneurship from startup to scaleup: The role of 31

Venture Capital funds and Angel Groups 
Elitzur, R., \& Gavious, A. (2003). Contracting, signaling, and moral hazard: A model of entrepreneurs, 'angels,'and venture capitalists. Journal of Business Venturing, 18(6), 709-725.

European Commission (2015). Digital Transformation of European Industry and Enterprises; A report of the Strategic Policy Forum on Digital Entrepreneurship, available from: http://ec.europa.eu/DocsRoom/documents/9462/attachments/1/translations/en/renditions/native

European Venture Capital Association (EVCA) - Annual Report 2016; https://www.investeurope.eu/newsopinion/publications/\#i

Fairchild, R. (2011). An entrepreneur's choice of venture capitalist or angel-financing: A behavioral gametheoretic approach. Journal of Business Venturing, 26(3), 359-374.

Fischer, E., \& Reuber, A. (2011). Social interaction via new social media:(how) can interactions on twitter affect effectual thinking and behaviour. Journal of Business Venturing, 26(1), 1-18.

Fisher, G., Kotha, S., \& Lahiri, A. (2016). Changing with the times: An integrated view of identity, legitimacy, and new venture life cycles. Academy of Management Review, 41(3), 383-409.

Freear, J., Sohl, J. E., \& Wetzel Jr, W. E. (1994). Angels and non-angels: Are there differences? Journal of Business Venturing, 9(2), 109-123.

Freear, J., Sohl, J. E., \& Wetzel, W. (2002). Angles on angels: Financing technology-based ventures-a historical perspective. Venture Capital: An International Journal of Entrepreneurial Finance, 4(4), 275287.

Gaibraith, J. (1982). The stages of growth. Journal of Business Strategy, 3(1), 70-79.

Galbraith, C. S., DeNoble, A. F., \& Ehrlich, S. B. (2009). The use and content of formal rating systems in angel group investment initial screening stages. Journal of Small Business Strategy, 20(2), 61-79.

Ghezzi, A. \& Cavallo, A. 2018, Agile business model innovation in digital entrepreneurship: Lean Startup approaches, Journal of Business Research

Gompers, P., \& Lerner, J. (1999). An analysis of compensation in the US venture capital partnership1. Journal of Financial Economics, 51(1), 3-44.

Gompers, P., \& Lerner, J. (2001). The venture capital revolution. Journal of Economic Perspectives, 15(2), $145-168$

Grilli, L., \& Murtinu, S. (2014). Government, venture capital and the growth of european high-tech entrepreneurial firms. Research Policy, 43(9), 1523-1543.

Greiner, L. E. (1972). The Greiner growth model. Harvard Business Review.

Guerini, M., \& Quas, A. (2016). Governmental venture capital in europe: Screening and certification. Journal of Business Venturing, 31(2), 175-195.

Gupta, A. K., \& Govindarajan, V. (1984). Business unit strategy, managerial characteristics, and business unit effectiveness at strategy implementation. Academy of Management Journal, 27(1), 25-41.

Hahn, D., Minola, T. \& Eddleston, K. (2018). How do scientists contribute to the performance of innovative startups? An imprinting perspective on open innovation. Journal of Management Studies.

Cavallo et al., (2019). Fostering Digital Entrepreneurship from startup to scaleup: The role of 32 Venture Capital funds and Angel Groups 
Harding, D., \& Pagan, A. (2002). Dissecting the cycle: A methodological investigation. Journal of Monetary Economics, 49(2), 365-381.

Harrison, R. T., \& Mason, C. M. (1992). International perspectives on the supply of informal venture capital. Journal of Business Venturing, 7(6), 459-475.

Hayward, M. L., Shepherd, D. A., \& Griffin, D. (2006). A hubris theory of entrepreneurship. Management Science, 52(2), 160-172.

Hellmann, T., \& Puri, M. (2002). Venture capital and the professionalization of start-up firms: Empirical evidence. The Journal of Finance, 57(1), 169-197.

Hellmann, T., \& Thiele, V. (2015). Friends or foes? the interrelationship between angel and venture capital markets. Journal of Financial Economics, 115(3), 639-653.

Henrekson, M., \& Johansson, D. (2010). Gazelles as job creators: a survey and interpretation of the evidence. Small business economics, 35(2), 227-244.

Huang, J., Henfridsson, O., Liu, M. J., \& Newell, S. (2017). Growing on steroids: Rapidly scaling the user base of digital ventures through digital innovaton. MIS Quarterly, 41(1)

Isenberg, D., \& Onyemah, V. (2016). Fostering scaleup ecosystems for regional economic growth (innovations case narrative: Manizales-mas and scale up milwaukee). Innovations: Technology, Governance, Globalization, 11(1-2), 60-79.

Kauffman Foundation, 2014. Date of last access: 19/07/2018. https://www.kauffman.org/blogs/currents/2014/10/smoothing-the-path-for-new-firms

Kerr, W. R., Lerner, J., \& Schoar, A. (2011). The consequences of entrepreneurial finance: Evidence from angel financings. The Review of Financial Studies, 27(1), 20-55.

Khavul, S. (2010). Microfinance: Creating opportunities for the poor? Academy of Management Perspectives, 24(3), 58-72.

Lerner, J., Schoar, A., Sokolinski, S., \& Wilson, K. (2018). The globalization of angel investments: Evidence across countries. Journal of Financial Economics, 127(1), 1-20.

Lowe, R. A., \& Ziedonis, A. A. (2006). Overoptimism and the performance of entrepreneurial firms. Management Science, 52(2), 173-186.

Malecki, E. J. (2018). Entrepreneurship and entrepreneurial ecosystems. Geography Compass, 12(3), e12359.

Marmer, M., Herrmann, B. L., Dogrultan, E., Berman, R., Eesley, C., \& Blank, S. (2011). Startup genome report extra: Premature scaling. Startup Genome, 10, 1-56.

Mason, C. M., \& Harrison, R. T. (2000). The size of the informal venture capital market in the united kingdom. Small Business Economics, 15(2), 137-148.

Mason, C., \& Harrison, R. (1992). The supply of equity finance in the UK: A strategy for closing the equity gap. Entrepreneurship \& Regional Development, 4(4), 357-380.

May, J. (2002). Structured angel groups in the USA: The dinner club experience. Venture Capital: An International Journal of Entrepreneurial Finance, 4(4), 337-342.

Cavallo et al., (2019). Fostering Digital Entrepreneurship from startup to scaleup: The role of 33

Venture Capital funds and Angel Groups 
Mintzberg, H. (1984). Power and organization life cycles. Academy of Management Review, 9(2), 207-224.

Minola, T., Vismara, S., \& Hahn, D. (2017). Screening model for the support of governmental venture capital. The Journal of Technology Transfer, 42(1), 59-77.

Nambisan, S. (2017). Digital entrepreneurship: Toward a digital technology perspective of entrepreneurship. Entrepreneurship Theory and Practice, 41(6), 1029-1055.

Onetti, A. (2014). Scaleups. when does a startup turn into a scaleup? Startup Europe Partnership, 29

Orser, B. J., Hogarth-Scott, S., \& Riding, A. L. (2000). Performance, firm size, and management problem solving. Journal of Small Business Management, 38(4), 42.

Parker, G. G., Van Alstyne, M. W., \& Choudary, S. P. (2016). Platform revolution: How networked markets are transforming the economyand how to make them work for you WW Norton \& Company.

Prasad, A., Venkatesh, R., \& Mahajan, V. (2010). Optimal bundling of technological products with network externality. Management Science, 56(12), 2224-2236.

Payne, W. H., \& Macarty, M. J. (2002). The anatomy of an angel investing network: Tech coast angels. Venture Capital: An International Journal of Entrepreneurial Finance, 4(4), 331-336.

Penrose, E. T. (1959). The theory of the growth ofthe firm. New York: Sharpe,

Petty, J. S., \& Gruber, M. (2011). "In pursuit of the real deal”: A longitudinal study of VC decision making. Journal of Business Venturing, 26(2), 172-188.

Phelps, R., Adams, R., \& Bessant, J. (2007). Life cycles of growing organizations: A review with implications for knowledge and learning. International Journal of Management Reviews, 9(1), 1-30.

Prowse, S. (1998). Angel investors and the market for angel investments. Journal of Banking \& Finance, 22(68), 785-792.

Puri, M., \& Zarutskie, R. (2008). On the Lifecycle Dynamics of Venture-Capital-and Non-Venture-CapitalFinanced Firms.EFA 2007 Ljubljana Meetings Paper; US Census Bureau Center for Economic Studies Paper no,

Puri, M., \& Zarutskie, R. (2012). On the life cycle dynamics of venture-capital-and non-venture-capitalfinanced firms. The Journal of Finance, 67(6), 2247-2293.

Ries, E. (2011). The lean startup: How today's entrepreneurs use continuous innovation to create radically successful businesses. Crown Books.

Sapienza, H. J. (1992). When do venture capitalists add value? Journal of Business Venturing, 7(1), 9-27.

Sapienza, H. J., \& Gupta, A. K. (1994). Impact of agency risks and task uncertainty on venture capitalist-CEO interaction. Academy of Management Journal, 37(6), 1618-1632.

Simon, M., \& Shrader, R. C. (2012). Entrepreneurial actions and optimistic overconfidence: The role of motivated reasoning in new product introductions. Journal of Business Venturing, 27(3), 291-309.

Sims, M. A., \& O'Regan, N. (2006). In search of gazelles using a research DNA model. Technovation, 26(8), 943-954. 
Sohl, J. (2012). The changing nature of the angel market. The Handbook of Research on Venture Capital, 2, $17-41$.

Sorenson, O., \& Stuart, T. E. (2001). Syndication networks and the spatial distribution of venture capital investments. American Journal of Sociology, 106(6), 1546-1588.

Sørheim, R., \& Landström, H. (2001). Informal investors-A categorization, with policy implications. Entrepreneurship \& Regional Development, 13(4), 351-370.

Stam, E., Bosma, N., van Witteloostuijn, A., de Jong, J., Bogaert, S., Edwards, N., \& Jaspers, F. (2012). Ambitious entrepreneurship: A review of the state of the art.

Steininger, D. M. (2019). Linking information systems and entrepreneurship: A review and agenda for ITassociated and digital entrepreneurship research. Information Systems Journal, 29(2), 363-407.

Stuart, T. E., Hoang, H., \& Hybels, R. C. (1999). Interorganizational endorsements and the performance of entrepreneurial ventures. Administrative Science Quarterly, 44(2), 315-349.

Shah, S. K., \& Tripsas, M. (2007). The accidental entrepreneur: The emergent and collective process of user entrepreneurship. Strategic entrepreneurship journal, 1(1-2), 123-140.

Tian, X. (2011). The causes and consequences of venture capital stage financing. Journal of Financial Economics, 101(1), 132-159.

Timmons, J. A., \& Bygrave, W. D. (1986). Venture capital's role in financing innovation for economic growth. Journal of Business Venturing, 1(2), 161-176.

Tyebjee, T. T., \& Bruno, A. V. (1984). A model of venture capitalist investment activity. Management Science, 30(9), 1051-1066.

Van Osnabrugge, M., \& Robinson, R. J. (2000). Angel investing: Matching startup funds with startup companies--the guide for entrepreneurs and individual investors John Wiley \& Sons.

Venkataraman, S. (1997). The distinctive domain of entrepreneurship research. Advances in Entrepreneurship, Firm Emergence and Growth, 3(1), 119-138.

von Briel, F., Davidsson, P., \& Recker, J. (2018). Digital technologies as external enablers of new venture creation in the IT hardware sector. Entrepreneurship Theory and Practice, 42(1), 47-69.

Wetzel, W. (1981). " informal risk capital in new england". in vesper, K H.(ed.), frontiers of entrepreneurship research.

Wetzel, W. E. (1983). Angels and informal risk capital. Sloan Management Review, 24(4), 23-34.

Wilson, K. (2011). Financing high-growth firms: The role of angel investors.

Wong, A., Bhatia, M., \& Freeman, Z. (2009). Angel finance: The other venture capital. Strategic Change: Briefings in Entrepreneurial Finance, 18(7-8), 221-230.

Zacharakis, A. L., \& Meyer, G. D. (2000). The potential of actuarial decision models: Can they improve the venture capital investment decision? Journal of Business Venturing, 15(4), 323-346.

Zhang, S. X., \& Cueto, J. (2017). The study of bias in entrepreneurship. Entrepreneurship Theory and Practice, 41(3), 419-454.

Cavallo et al., (2019). Fostering Digital Entrepreneurship from startup to scaleup: The role of 35

Venture Capital funds and Angel Groups 


\section{APPENDIX}

Table A1 - Robustness check about the Regression Model predicting Revenues Growth of digital ventures and digital scaleups

\begin{tabular}{lcrrr}
\hline & MODEL 1.III & \multicolumn{2}{c}{ MODEL 3.III } \\
\multicolumn{1}{c}{ (digital new venture) } & (digital Scaleup) \\
\multicolumn{1}{c}{ Coefficient } & T-Stat. & Coefficient & T-Stat. \\
\hline$F V C$ & $0.468^{* * *}$ & 4.962 & $0.662 * *$ & 2.622 \\
$I V C$ & 0.118 & 1.490 & 0.195 & 0.904 \\
$D V$ & $(0.061)$ & 1.719 & $(0.141)$ & 1.633 \\
$D V A$ & $(0.001)$ & 0.027 & $(0.011)$ & 0.096 \\
$Y$ & 0.035 & 0.899 & $(0.003)$ & 0.034 \\
$N I$ & $(0.030)$ & 0.796 & $(0.035)$ & 0.426 \\
$R N$ & $(0.013)$ & 0.298 & 0.000 & 0.003 \\
$C C$ & $0.263 * *$ & 3.342 & 0.255 & 1.097 \\
$P R$ & $0.177 * * *$ & 3.522 & $0.267 *$ & 2.102 \\
$I N D$ & $(0.042)$ & 1.196 & 0.009 & 0.109 \\
$L O C$ & $(0.009)$ & 0.252 & 0.071 & 0.888 \\
$F V C^{2}$ & $(0.078)$ & 0.786 & $(0.286)$ & 1.053 \\
$I V C^{2}$ & $(0.091)$ & 1.216 & $(0.142)$ & 0.735 \\
\hline$R^{2}$ & 0.569 & & 0.661 & \\
$A d j R^{2}$ & 0.553 & & 0.585 & \\
\hline
\end{tabular}

Structural estimates (*: $p<0.5 ; * *: p<0.01 ; * * *: p<0.001)$. 